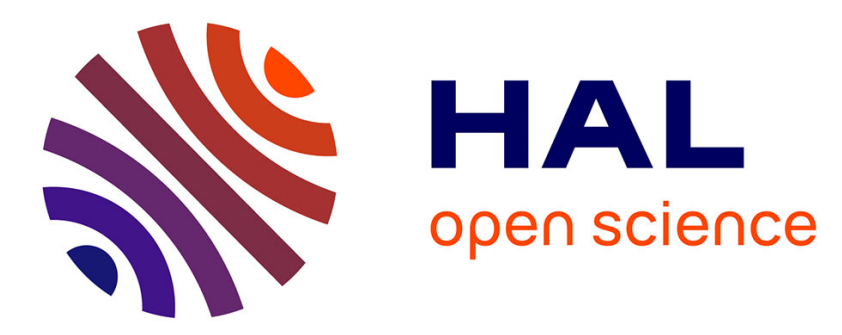

\title{
The role of marine aerosol in the formation of (double) sulfate/nitrate salts in plasters
}

Héctor Morillas, Maite Maguregui, Céline Paris, Ludovic Bellot-Gurlet, Philippe Colomban, Juan Manuel Madariaga

\section{To cite this version:}

Héctor Morillas, Maite Maguregui, Céline Paris, Ludovic Bellot-Gurlet, Philippe Colomban, et al.. The role of marine aerosol in the formation of (double) sulfate/nitrate salts in plasters. Microchemical Journal, 2015, 123, pp.148 - 157. 10.1016/j.microc.2015.06.004 . hal-01546564

\author{
HAL Id: hal-01546564 \\ https://hal.science/hal-01546564
}

Submitted on 12 Jul 2018

HAL is a multi-disciplinary open access archive for the deposit and dissemination of scientific research documents, whether they are published or not. The documents may come from teaching and research institutions in France or abroad, or from public or private research centers.
L'archive ouverte pluridisciplinaire HAL, est destinée au dépôt et à la diffusion de documents scientifiques de niveau recherche, publiés ou non, émanant des établissements d'enseignement et de recherche français ou étrangers, des laboratoires publics ou privés. 


\title{
The role of marine aerosol in the formation of (double) sulfate/nitrate salts in plasters
}

\author{
Héctor Morillas $^{\mathrm{a}, *}$, Maite Maguregui ${ }^{\mathrm{b}}$, Celine Paris ${ }^{\mathrm{c}}$, Ludovic Bellot-Gurlet ${ }^{\mathrm{c}}$, \\ Philippe Colomban ${ }^{\mathrm{c}}$, Juan Manuel Madariaga ${ }^{\mathrm{a}, \mathrm{d}}$ \\ a Department of Analytical Chemistry, Faculty of Science and Technology, University of the Basque Country UPV/EHU, P.O. Box 644, 48080 Bilbao, Basque Country, Spain \\ ${ }^{b}$ Department of Analytical Chemistry, Faculty of Pharmacy, University of the Basque Country UPV/EHU, P.O. Box 450, 01080 Vitoria-Gasteiz, Basque Country, Spain

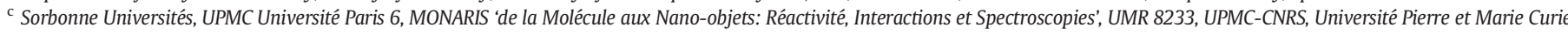 \\ Paris 6, 75252, Paris, France \\ ${ }^{\mathrm{d}}$ Unesco Chair of Cultural Landscape and Heritage, University of the Basque Country UPV/EHU, P.O. Box 450, 01080 Vitoria-Gasteiz, Basque Country, Spain
}

\section{A R T I C L E I N F O}

\section{Article history:}

Received 12 May 2015

Received in revised form 7 June 2015

Accepted 8 June 2015

Available online 19 June 2015

\section{Keywords:}

Gypsum

Marine aerosol

Sulfates

Nitrates

Raman imaging

SEM-EDS imaging

\begin{abstract}
A B S T R A C T
During decades the use of gypsum in different buildings has been very common, especially in the Atlantic lands of Europe. Decay compounds like salt crystallizations are ones of the principal deterioration factors of such historical buildings. In this study, gypsum-based plasters from different inner rooms of the Igueldo Lighthouse (San Sebastian, Spain), a building dated back to 1860 that has been subjected to several repairs within these years, were investigated in order to ascertain the main mineral phases produced during the weathering process. A combination of Raman spectroscopy, X-ray diffraction, infrared spectroscopy in ATR mode, SEM-EDS imaging and Raman imaging was successfully applied to study the distribution of different decay compounds in the gypsum-based matrix and to establish the decay reaction pathway which leads to the formation of the identified decay compounds. Additionally thermodynamic chemical modeling was also performed to explain the formation of specific decaying compounds. According to the location of Igueldo Lighthouse (just above a cliff, close to the sea), this building experiments a wide influence of the marine aerosol $\left(\mathrm{Na}^{+}, \mathrm{K}^{+}, \mathrm{Mg}^{2+}, \mathrm{Cl}^{-}\right.$and $\mathrm{NO}_{3}^{-}$input $)$ and the influence of a high damp environment, giving rise to common efflorescence salts as well as to different mixed-calcium sulfates and mixed sulfate-nitrate salts, such as glauberite, syngenite, polyhalite and humberstonite. Dehydration process of gypsum from the plaster (leading to the presence of anhydrite and bassanite) was also identified.
\end{abstract}

(C) 2015 Elsevier B.V. All rights reserved.

\section{Introduction}

Gypsum $\left(\mathrm{CaSO}_{4} \cdot 2 \mathrm{H}_{2} \mathrm{O}\right)$ is one of the oldest materials used in construction. In the Neolithic period, with the development of fire based technologies, calcined gypsum plaster began to be developed, and it was used to assemble the pieces of masonry, seal the joints of the walls and to cover the walls of the houses, being progressively an alternative to the mud mortar. Since that time it began using regularly until nowadays, especially in the Atlantic lands of Europe. During production process, depending on the temperature and duration of the heating, gypsum converts to the hemihydrate (bassanite $\mathrm{CaSO}_{4} \cdot 1 / 2 \mathrm{H}_{2} \mathrm{O}$ ) or to an anhydrous form (anhydrite $\mathrm{CaSO}_{4}$ ). Water partial pressure control is difficult and thus $\mathrm{CaSO}_{4}-\mathrm{H}_{2} \mathrm{O}$ system highly variable and phase equilibrium depends on grain size and thermal treatment kinetics. Recent studies have demonstrated that, under atmospheric pressure [1,2], there are up to five compounds produced in this system, such as $\mathrm{CaSO}_{4} \cdot 2 \mathrm{H}_{2} \mathrm{O}$ (gypsum, monoclinic), $\mathrm{CaSO}_{4} \cdot \frac{1}{2} \mathrm{H}_{2} \mathrm{O}$ (bassanite monoclinic/rhombohedral),

\footnotetext{
* Corresponding author.

E-mail address: hector.morillas@ehu.es (H. Morillas).
}

$\gamma-\mathrm{CaSO}_{4}$ (anhydrite I, or AI, cubic), $\beta-\mathrm{CaSO}_{4}$ (anhydrite II, or AII, orthorhombic) and $\alpha-\mathrm{CaSO}_{4}$ (anhydrite III, or AIII, hexagonal). Depending on the pressure (neon gas as pressure-transmitting medium) and gradient, different mineral phases in the dehydration of the $\mathrm{CaSO}_{4}-\mathrm{H}_{2} \mathrm{O}$ system can suffer deformations in their structure $[3,4]$.

In the literature there are several studies that remark also the high influence of organic and inorganic additives which they have been used since the second half of the 20th century in order to control the hydration in gypsum setting/production [5-7]. Sometimes $\mathrm{NaCl}, \mathrm{MgCl}_{2}$, $\mathrm{CaCl}_{2}$ solutions can dehydrate gypsum as a result of the lower water vapour pressure of these solutions, modifying its solubility [8]. The later compounds, together with nitrates and sulfates, are present in marine aerosol [9], besides of fatty acids [10]. Some authors point out that in marine aerosol a mixture of ions like $\mathrm{Na}^{+}, \mathrm{Ca}^{2+}, \mathrm{Mg}^{2+}, \mathrm{K}^{+}, \mathrm{Cl}^{-}, \mathrm{Br}^{-}$, $\mathrm{I}^{-}, \mathrm{Li}^{+}, \mathrm{NO}_{3}^{-}, \mathrm{NH}_{4}^{+}, \mathrm{SO}_{4}^{2-}$ and $\mathrm{CO}_{3}^{2-}$ are usually present along with structural water and other less common ions from anthropogenic sources (e.g., $\mathrm{Ba}^{2+}, \mathrm{Sr}^{2+}, \mathrm{Pb}^{2+}, \mathrm{VO}_{2}^{-}$) [11-13]. In this way, in the marine aerosol composition, natural and anthropogenic ion inputs are present $[14,15]$. There are studies that simulated the reactions between cations and anions in the complex $\mathrm{Na}^{+}, \mathrm{K}^{+}, \mathrm{Ca}^{2+}, \mathrm{Cl}^{-}, \mathrm{SO}_{4}^{2}--\mathrm{H}_{2} \mathrm{O}$ system [16], 
which can occur in natural environment, promoting the formation of different type of sulfates.

In the literature, several studies describe the formation of decay compounds in building materials as a consequence of the reactions between the original compounds and the ions transported in the marine aerosol. The main pathologies promoted due to these reactions are the formation of efflorescence, sub-efflorescence, loosing and detachment of the building materials, etc. [17-22]. Different decay compounds which have been detected inside the porous and/or over the gypsum surface or in presence of gypsum are listed in Table 1.

Moreover, theoretical models based on density functional theory calculations of the structures and properties of compounds like anhydrite $\left(\mathrm{CaSO}_{4}\right)$, polyhalite $\left(\mathrm{K}_{2} \mathrm{Ca}_{2} \mathrm{Mg}\left(\mathrm{SO}_{4}\right)_{4} \cdot 2 \mathrm{H}_{2} \mathrm{O}\right)$ and carnallite $\left(\mathrm{KMgCl}_{3} \cdot 6 \mathrm{H}_{2} \mathrm{O}\right)$ (the last two related with marine influence) have been studied [33]. Other authors, using techniques such as XRD and SEM-EDS have demonstrated the influence and direct relationship that exists in the formation of gypsum and glauberite with the marine aerosol; and their seasons' dependence/periodicity [34].

In this work, a combination of different analytical techniques, including Raman spectroscopy, X-ray diffraction and infrared spectroscopy in ATR mode have been used to identify different decay compounds formed on gypsum plasters from indoor areas of an historical building located in front of the sea, the Igueldo Lighthouse (Donostia-San Sebastian, north of Spain). Moreover, to complete and corroborate the point-bypoint spectroscopic results, SEM-EDS imaging and Raman imaging were used to map the distribution of the different decay compounds crystallized on gypsum-based plasters. Finally, thermodynamic calculations to complete the analytical statements taking into account the high influence of marine environment were carried out.

\section{Materials and methods}

\subsection{Samplings}

Plaster samples from the walls of the Lighthouse machine room, where the temperature conditions inside the room range between $27{ }^{\circ} \mathrm{C}$ (winter time) and $35^{\circ} \mathrm{C}$ (summer time) with a wide range of relative humidity ( $>90 \%$ ) were collected using a scalpel. The size of all of them never exceeded $2 \times 2 \mathrm{~cm}^{2}$. Plaster fragments were analyzed directly by means of point-by-point Raman spectroscopy. For the XRD, ATR-FTIR, SEM-EDS imaging and Raman imaging, the same samples were powdered.

\subsection{Instrumentation}

The SEM-EDS analyses were carried out using a EVO®40 Scanning Electron Microscope (Carl Zeiss NTS GmbH, Germany) coupled to an $\mathrm{X}$-Max energy-dispersive X-ray spectrometer (Oxford Instruments,

Table 1

Mineral phases identified in plaster.

\begin{tabular}{lll}
\hline Mineral phase & Chemical formula & Reference \\
\hline Bassanite & $\mathrm{CaSO}_{4} \cdot \frac{1}{2} \mathrm{H}_{2} \mathrm{O}$ & {$[21]$} \\
Anhydrite, types I, II and III & $\mathrm{CaSO}_{4}$ & {$[1,23]$} \\
Glauberite & $\mathrm{CaNa}_{2}\left(\mathrm{SO}_{4}\right)_{2}$ & {$[24,25]$} \\
Thenardite & $\mathrm{Na}_{2} \mathrm{SO}_{4}$ & {$[26,27]$} \\
Mirabilite & $\mathrm{Na}_{2} \mathrm{SO}_{4} \cdot 10 \mathrm{H}_{2} \mathrm{O}$ & {$[28]$} \\
Metastable mirabillite & $\mathrm{Na}_{2} \mathrm{SO}_{4} \cdot 7 \mathrm{H}_{2} \mathrm{O}$ & \\
Mascagnite & $\left(\mathrm{NH}_{4}\right)_{2} \mathrm{SO}_{4}$ & {$[21]$} \\
Epsomite & $\mathrm{MgSO}_{4} \cdot 7 \mathrm{H}_{2} \mathrm{O}$ & {$[29]$} \\
(para) Coquimbite & $\mathrm{Fe}_{2}\left(\mathrm{SO}_{4}\right)_{3} \cdot 9 \mathrm{H}_{2} \mathrm{O}$ & {$[27]$} \\
Syngenite & $\mathrm{K}_{2} \mathrm{Ca}_{2}\left(\mathrm{SO}_{4}\right) \cdot \mathrm{H}_{2} \mathrm{O}$ & {$[29]$} \\
Starkeyite & $\mathrm{MgSO}_{4} \cdot 4 \mathrm{H}_{2} \mathrm{O}$ & {$[21]$} \\
Hexahydrite & $\mathrm{MgSO}_{4} \cdot 6 \mathrm{H}_{2} \mathrm{O}$ & {$[30]$} \\
Eugsterite & $\mathrm{Na}_{4} \mathrm{Ca}_{2}\left(\mathrm{SO}_{4}\right)_{3} \cdot \mathrm{H}_{2} \mathrm{O}$ & {$[30]$} \\
Darapskite & $\mathrm{Na}_{3}\left(\mathrm{SO}_{4}\right)\left(\mathrm{NO}_{3}\right) \cdot \mathrm{H}_{2} \mathrm{O}$ & {$[31]$} \\
Polyhalite & $\mathrm{K}_{2} \mathrm{Ca}_{2} \mathrm{Mg}_{(2}\left(\mathrm{SO}_{4}\right)_{4} \cdot 2 \mathrm{H}_{2} \mathrm{O}$ & {$[32]$} \\
\hline
\end{tabular}

Abingdon, Oxfordshire, United Kingdom) for electron image acquisitions and elemental analysis (punctual and imaging). Although gypsum alone is not conductive, it was possible to obtain optimal results without carbon or gold coating. The SEM images were obtained at high vacuum employing an acceleration voltage of $30 \mathrm{kV}$ and a $10-400 \mu \mathrm{m}$ working distance. Different magnifications (reaching up to $\times 6800$ ) were used for secondary electron images and an integration time of $50 \mathrm{~s}$ was employed to improve the signal-to-noise ratio. The EDS spectra were acquired and treated using the INCA software. Furthermore, a mapping of specific microscopic areas in the samples was possible, allowing the evaluation of the distribution of these elements over the sample.

ATR-FTIR spectra were recorded using a Bruker Equinox 55 spectrometer equipped with an extended $\mathrm{KBr}$ Beamsplitter and purged with dried air. A liquid nitrogen-cooled MCT detector or a Peltiercooled DTGS Mid-IR detector was used. Two hundred scans were accumulated between 4000 and $600 \mathrm{~cm}^{-1}$ with a $4 \mathrm{~cm}^{-1}$ resolution with the help of an extended $\mathrm{KBr}$ Beamsplitter. A background was collected before each sample's spectra and additional atmospheric compensation was provided by Opus 6.5 Software. Few milligrams of sample powder are required for each measurement using an ATR diamond crystal accessory (Golden Gate ${ }^{\circledR}$, Specac) which no require any additional sample preparation constraints. The obtained spectra were compared with the spectra of pure standard compounds contained in RRUFF [35] and in the e-VISART infrared databases [36].

The XRD analyses were performed with a PANalytical Xpert PRO powder diffractometer, equipped with a copper tube $\left(\lambda_{\mathrm{CuK} \alpha 1}=\right.$ $1.54060 \AA$, $\lambda_{\text {CuK } \alpha 2}=1.54439 \AA$ ), vertical goniometer (Bragg-Brentano geometry), programmable divergence aperture, automatic interchange of samples and secondary monochromator from graphite and PixCel detector. The measurement conditions were $40 \mathrm{kV}$ and $40 \mathrm{~mA}$, with an angular range $(2 \theta)$ scanned from 5 to $70^{\circ}$. The X'pert HighScore (PANalytical) software in combination with the specific powder diffraction file database (International Centre for Diffraction Data-ICDD, Pennsylvania, USA) was used for the phase identification.

For micro-Raman spectra and Raman Imaging, a Senterra spectrometer (Bruker Optics, Karlsruhe, Germany) equipped with a Peltiercooled charge-coupled device detector and $\times 10$ and $\times 50$ long working distance Olympus objectives was used to collect the Raman spectra excited under a $785 \mathrm{~nm}$ light from a diode laser. The Raman image acquisitions of specific areas of the plaster matrix were conducted using the Peak Pick Singular option. The interpretation of all the Raman results was performed by comparing the acquired Raman spectra with the Raman spectra of pure standard compounds collected in the e-VISNICH dispersive Raman database [37]. Additionally, free Raman databases (e.g. RRUFF [35]) were also considered for the assignation of unknown Raman bands. Different spectral analysis tools, OPUS ${ }^{\odot} 7.0$ (Bruker Optik GmbH, Ettlingen, Germany (2011)) for Raman Imaging; and Omnic 7.2 (Nicolet) and Wire 2.0 (Renishaw) for spectral treatment and assignation, were used.

Thermodynamic chemical modeling was also performed to explain the formation of specific decaying compounds, considering the composition of the plaster and the input of ions infiltrated in the material. For that purpose the MEDUSA [38] free academic program was used. This program implements its own Hydrochemical Equilibrium-Constant (HYDRA) database. This database was extended manually introducing the logarithm of the formation constant of specific mineralogical phases of interest [39]. Certain constants were obtained also from the Visual MINTEQ [40] database.

\section{Results and discussion}

\subsection{Point-by-point Raman spectroscopy analyses}

In the Raman spectra acquired on the gypsum plaster samples, different kind of sulfates and nitrates bands were distinguished. Most of the bands are centered between $960-1080 \mathrm{~cm}^{-1}$ as in Fig. 1 is illustrated. 
This underlines the simultaneous presence of several sulfates such as syngenite $\left(\mathrm{K}_{2} \mathrm{Ca}\left(\mathrm{SO}_{4}\right)-\cdot \mathrm{H}_{2} \mathrm{O}\right.$, Raman band at $\left.981 \mathrm{~cm}^{-1}\right)$, thenardite $\left(\mathrm{Na}_{2} \mathrm{SO}_{4}\right.$, Raman band at $\left.989 \mathrm{~cm}^{-1}\right)$, starkeyite $\left(\mathrm{MgSO}_{4} \cdot 4 \mathrm{H}_{2} \mathrm{O}\right.$, Raman band at $\left.1001 \mathrm{~cm}^{-1}\right)$ and gypsum $\left(\mathrm{CaSO}_{4} \cdot 2 \mathrm{H}_{2} \mathrm{O}\right.$, Raman band $1008 \mathrm{~cm}^{-1}$ ). In the same micronic spot (under x100 objective) nitrates such as niter $\left(\mathrm{KNO}_{3}\right.$, Raman band at $\left.1048 \mathrm{~cm}^{-1}\right)$ and nitratine $\left(\mathrm{NaNO}_{3}\right.$, Raman band at $1067 \mathrm{~cm}^{-1}$ ) were also identified (see Fig. 1). Other compounds identified through Raman analyses include sulfates such as epsomite $\left(\mathrm{MgSO}_{4} \cdot 7 \mathrm{H}_{2} \mathrm{O}\right)$, hexahydrite $\left(\mathrm{MgSO}_{4} \cdot 6 \mathrm{H}_{2} \mathrm{O}\right)$, mirabilite $\left(\mathrm{Na}_{2} \mathrm{SO}_{4} \cdot 10 \mathrm{H}_{2} \mathrm{O}\right)$, bassanite or gypsum hemihydrate $\left(\mathrm{CaSO}_{4} \cdot \frac{1}{2} \mathrm{H}_{2} \mathrm{O}\right)$ and anhydrite $\left(\mathrm{CaSO}_{4}\right)$.

\subsection{X-ray diffraction and point-by-point Raman spectroscopy revision}

To corroborate the Raman spectra assignation, X-ray powder diffraction (XRD) analyses were conducted on the collected samples. The acquired XRD spectra revealed the presence of different compounds, namely, quartz $\left(\mathrm{SiO}_{2}\right)$, gypsum $\left(\mathrm{CaSO}_{4} \cdot 2 \mathrm{H}_{2} \mathrm{O}\right)$, bassanite $\left(\mathrm{CaSO}_{4} \cdot \frac{1}{2} \mathrm{H}_{2} \mathrm{O}\right)$, polyhalite $\left(\mathrm{K}_{2} \mathrm{Ca}_{2} \mathrm{Mg}\left(\mathrm{SO}_{4}\right)_{4} \cdot 2 \mathrm{H}_{2} \mathrm{O}\right)$, glauberite $\left(\mathrm{CaNa}_{2}\left(\mathrm{SO}_{4}\right)_{2}\right)$, syngenite $\left(\mathrm{K}_{2} \mathrm{Ca}\left(\mathrm{SO}_{4}\right)_{2} \cdot \mathrm{H}_{2} \mathrm{O}\right)$ and humberstonite $\left(\mathrm{K}_{3} \mathrm{Na}_{7} \mathrm{Mg}_{2}\left(\mathrm{SO}_{4}\right)_{6}\left(\mathrm{NO}_{3}\right)_{2} \cdot 6 \mathrm{H}_{2} \mathrm{O}\right)$ (see Fig. 2). Considering that XRD hardly detect compounds which are below $5 \%$ in the sample and/or are amorphous [41], it is possible to say that the nitrates, sulfates and nitrate-sulfate salts detected are not in trace levels in the analyzed samples and these global analyses by XRD will take a general consideration of all phases.

Taking into account these XRD results, the acquired Raman spectra were re-examined searching the possible presence of overlapped Raman signals. For example, in Fig. 1, the signals at 981 and 1006 (shoulder in $1000 \mathrm{~cm}^{-1}$ region) $\mathrm{cm}^{-1}$ correspond to syngenite stretching mode; the bands at 989 and 1016 (shoulder in $1000 \mathrm{~cm}^{-1}$ region) $\mathrm{cm}^{-1}$ correspond to those of polyhalite; and the $1008 \mathrm{~cm}^{-1}$ peak to the main band of gypsum. Finally, the bands at 1013 (shoulder in $1000 \mathrm{~cm}^{-1}$ region), 1048 and $1067 \mathrm{~cm}^{-1}$ are clearly related with the stretching modes of humberstonite. Analyzing the whole spectrum shown in Fig. 1, secondary bands of those mineral phases can be ascertained. For example, peaks at 183,632 and $723 \mathrm{~cm}^{-1}$ belong to humberstonite; those at 414, 492, 669 and $1134 \mathrm{~cm}^{-1}$ belong to gypsum; and two weak bands at 436 and $652 \mathrm{~cm}^{-1}$ belong to polyhalite. Additionally, bands at $453,469,485,618,634,1155,1169 \mathrm{~cm}^{-1}$ belong to glauberite; and those at $441,492,642,1139 \mathrm{~cm}^{-1}$ belong to syngenite.

\subsection{ATR-FTIR analyses}

In order to search some complementary structural specificities of compounds, (i.e. the $\mathrm{OH}$ modes, or possibly less crystallized phases) gypsum plaster samples using ATR-FTIR were also analyzed. As an example, in Fig. 3 (top left) a representative ATR-FTIR spectrum obtained from the gypsum plaster, showing very complex and broad IR bands can be observed. In order to resolve (separate) the overlapped IR bands and

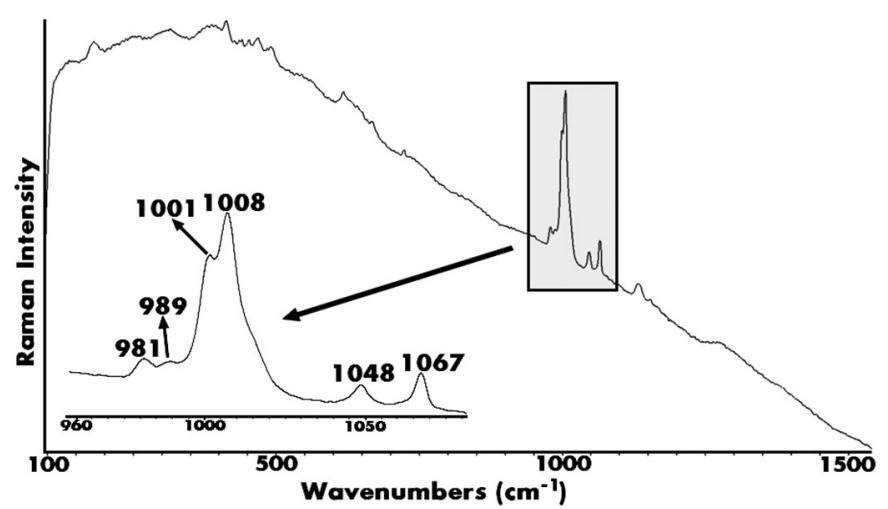

Fig. 1. Raman spectrum showing bands of compounds present in the gypsum-based plaster. taking into consideration the hypothesis of the similarities between the bandwidths for all compounds, a curve-fitting process based on Gaussian and Laurentian algorithms was applied using Grams 32 software (Galactica, Thermo, US) on three different regions which are common for all the collected IR spectra (Fig. 3). With this spectral-treatment, it was possible to separate gypsum, bassanite, anhydrite, humberstonite, syngenite, polyhalite and glauberite IR bands. Therefore, the IR observations provide us complementary information about the hydration $(\mathrm{OH}$ modes) of different compounds because of the specific sensitivity of this technique to some structural features. Concretely, the IR bands between 3650 and $3200 \mathrm{~cm}^{-1}$ belong to $\mathrm{OH}$ stretching mode of crystalline water molecules of the hydrated compounds present in the samples. The band at $3602 \mathrm{~cm}^{-1}$ is related with bassanite. The ones at 3532 and $3403 \mathrm{~cm}^{-1}$ are related with the presence of gypsum, while the peak at $3474 \mathrm{~cm}^{-1}$ belongs to polyhalite [35]. The peaks at 3334 and $3248 \mathrm{~cm}^{-1}$ can be assigned to the presence of syngenite [35].

In an intermediate range, some bands are observable, like those at 1620 and $1683 \mathrm{~cm}^{-1}$, related to the sulfate stretching mode of gypsum no water bending contribute to $1620-1660 \mathrm{~cm}^{-1}$ range, while the band at $1401 \mathrm{~cm}^{-1}$ could not be assigned to specific compound present in plaster matrix.

In the $1180-940 \mathrm{~cm}^{-1}$ range, after curve-fitting procedure different bands were identified. All the bands assigned in this area belong to the main bands of anhydrite $\left(1095 \mathrm{~cm}^{-1}\right)$, gypsum $\left(1105 \mathrm{~cm}^{-1}\right)$, glauberite $\left(1083 \mathrm{~cm}^{-1}\right)$, polyhalite $\left(1073 \mathrm{~cm}^{-1}\right)$ and humberstonite $\left(1052 \mathrm{~cm}^{-1}\right)$ $[35,42]$. Apart of those IR signals, the band at $1005 \mathrm{~cm}^{-1}$ is related with the main band of syngenite, together with their secondary stretching bands at 1125 and $1111 \mathrm{~cm}^{-1}$. The band at $1135 \mathrm{~cm}^{-1}$ could be related with both a secondary band of syngenite or polyhalite. The band at $986 \mathrm{~cm}^{-1}$ could belong to a secondary band of polyhalite or syngenite Moreover, the bands at 1033, 1022 and 964 were also observed but could not be assigned with those compounds.

Finally, in the third region, from 730-605 $\mathrm{cm}^{-1}$, IR bands related with syngenite $\left(675\right.$ and $\left.645 \mathrm{~cm}^{-1}\right)$, polyhalite $(656,620$ and $\left.600 \mathrm{~cm}^{-1}\right)$, glauberite $\left(630\right.$ and $\left.605 \mathrm{~cm}^{-1}\right)$ and gypsum $\left(668 \mathrm{~cm}^{-1}\right)$ were identified. Apart from this, two additional bands at 711 and $699 \mathrm{~cm}^{-1}$ were also observed, but it could not be assigned and related with the present compounds, which could be related with secondary bands of some nitrates.

This uncertainty was observed in practically all of the ATR-FTIR spectra collected from the samples, making difficult the unequivocal assignation of all the IR features to given compounds, especially in the case of compounds containing the nitrate anion.

\subsection{Imaging by SEM-EDS and Raman spectroscopy}

The molecular results described in the previous sections were confirmed using SEM-EDS (elemental analysis). Concretely, SEM-EDS imaging was applied in order to see the distribution of all the elements representative of each molecular phase identified using Raman, XRD and ATR-FTIR. In this way, in Fig. 4, the distribution of $\mathrm{K}, \mathrm{O}, \mathrm{S}, \mathrm{Mg}, \mathrm{Ca}$, $\mathrm{Si}, \mathrm{Na}$ and $\mathrm{Cl}$ in a microscopic area (around $70 \mu \mathrm{m}$ ) of the plaster can be observed. Analyzing the elemental mappings, halite, quartz, syngenite and polyhalite can be distinguished. Therefore, with the elemental analyses, the presence of $\mathrm{NaCl}$ was verified ( $\mathrm{NaCl}$ doesn't have Raman signature nor observable IR signal in the studied range due to its very ionic character). This example corroborates the good strategy using several techniques in order to obtain the most complete characterization.

As it is going to describe in the following section, $\mathrm{NaCl}$ input coming from marine aerosol plays an important role in the formation of most of the new mineral phases. As can be observed in Fig. 5, apart from halite quartz, syngenite and polyhalite, glauberite distribution was also observed using SEM-EDS imaging. Additionally, in Figs. 4 and 5, SEMEDS imaging showed the distribution of $\mathrm{Ca}, \mathrm{S}$ and $\mathrm{O}$ related with the gypsum $\left(\mathrm{CaSO}_{4} \cdot 2 \mathrm{H}_{2} \mathrm{O}\right)$ and also the distribution of $\mathrm{Na}, \mathrm{S}$ and $\mathrm{O}$ was 


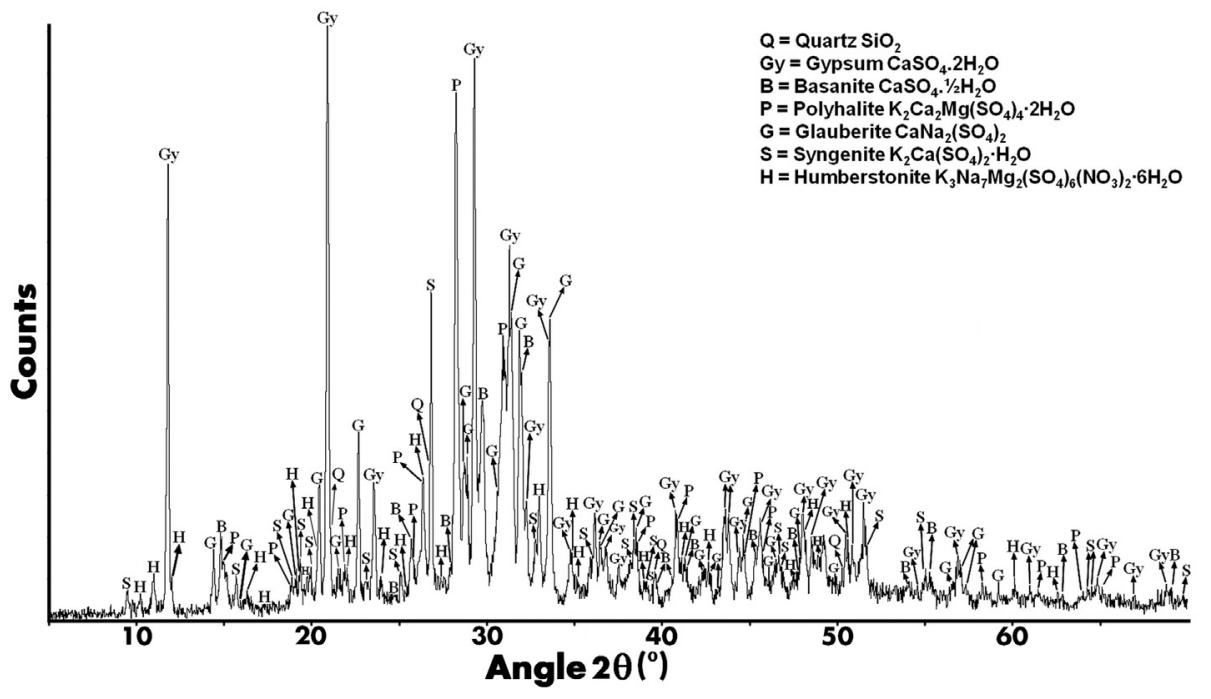

Fig. 2. Representative XRD spectrum of gypsum-based plaster showing the different bands of quartz, gypsum, bassanite, polyhalite, glauberite, syngenite and humberstonite.

clearly observable in certain areas, suggesting the presence of thenardite or mirabilite $\left(\mathrm{NaSO}_{4}-\mathrm{NaSO}_{4} \cdot 10 \mathrm{H}_{2} \mathrm{O}\right.$ system). This sodium sulfate system can also have an important influence in the decaying pathways affecting the matrix.

To confirm that the identified molecular phases are not crystallized in a punctual way, Raman imaging analysis were performed. As can be observed in Fig. 6 , the presence of glauberite $\left(\mathrm{CaNa}_{2}\left(\mathrm{SO}_{4}\right)_{2}\right)$ with its main Raman band at $1001 \mathrm{~cm}^{-1}$ (see Fig. 6A), polyhalite $\left(\mathrm{K}_{2} \mathrm{Ca}_{2} \mathrm{Mg}\left(\mathrm{SO}_{4}\right)_{4} \cdot 2 \mathrm{H}_{2} \mathrm{O}\right)$ with its main Raman bands at 1016 and $989 \mathrm{~cm}^{-1}$ (see Fig. 6B), gypsum $\left(\mathrm{CaSO}_{4} \cdot 2 \mathrm{H}_{2} \mathrm{O}\right)$ with its main Raman band at $1008 \mathrm{~cm}^{-1}$ (see Fig. 6C), humberstonite $\left(\mathrm{K}_{3} \mathrm{Na}_{7} \mathrm{Mg}_{2}\right.$ $\left.\left(\mathrm{SO}_{4}\right)_{6}\left(\mathrm{NO}_{3}\right)_{2} \cdot 6 \mathrm{H}_{2} \mathrm{O}\right)$ with its main Raman bands at 1013,1048 and $1067 \mathrm{~cm}^{-1}$ (see Fig. 6D) and syngenite $\left(\mathrm{K}_{2} \mathrm{Ca}\left(\mathrm{SO}_{4}\right)_{2} \cdot \mathrm{H}_{2} \mathrm{O}\right)$ with its main Raman bands at 981 and $1006 \mathrm{~cm}^{-1}$ (see Fig. 6E) were identified. Although the presence of anhydrite $\left(\mathrm{CaSO}_{4}\right)$ is clear, its Raman mapping was not added because it was difficult to mark exactly the peak at $1016 \mathrm{~cm}^{-1}$. From the images, the heterogeneity and the wide presence of these compounds in the gypsum plaster must be concluded.
Table 2 summarizes all the compounds detected by the five analytical techniques used to characterize the samples. The whole set of analyses conducted by ATR-FTIR, Raman spectroscopy and XRD revealed a complex system of decay compounds. The combined use of XRD data with the Raman spectroscopy information has demonstrated to be an adequate analytical methodology to avoid inaccurate assignments and to detect all the compounds present in different proportions within the samples. The information given by ATR-FTIR itself is not enough to identify the different phases, due to the broad width of IR bands. Finally the use of SEM-EDS and Raman Imaging, complement the analytical information of the decay compounds present in plaster.

\subsection{Decay pathways and mechanisms}

As seen in Table 2, a wide variety of decaying compounds were detected, containing ions like $\mathrm{Na}^{+}, \mathrm{K}^{+}, \mathrm{Mg}^{2+}$ and $\mathrm{NO}_{3}^{-}$, apart from the $\mathrm{Ca}^{2+}$ and $\mathrm{SO}_{4}^{2-}$ coming from the plaster matrix. According to the previous studies performed in the Igueldo Lighthouse [20,21], the deposition

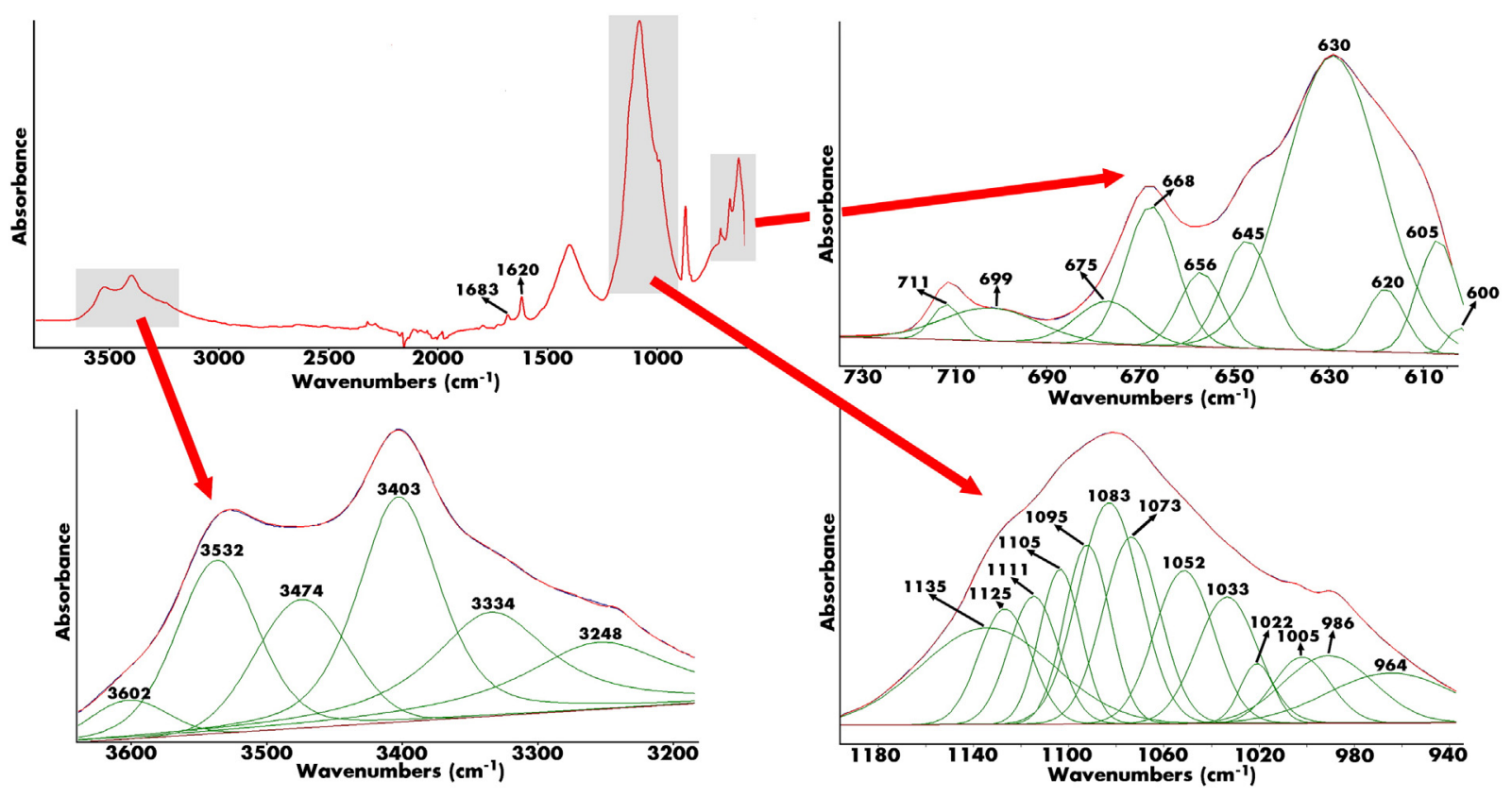

Fig. 3. ATR-FTIR spectrum of a plaster sample with some enlargement and band decomposition of three informative spectral ranges. 

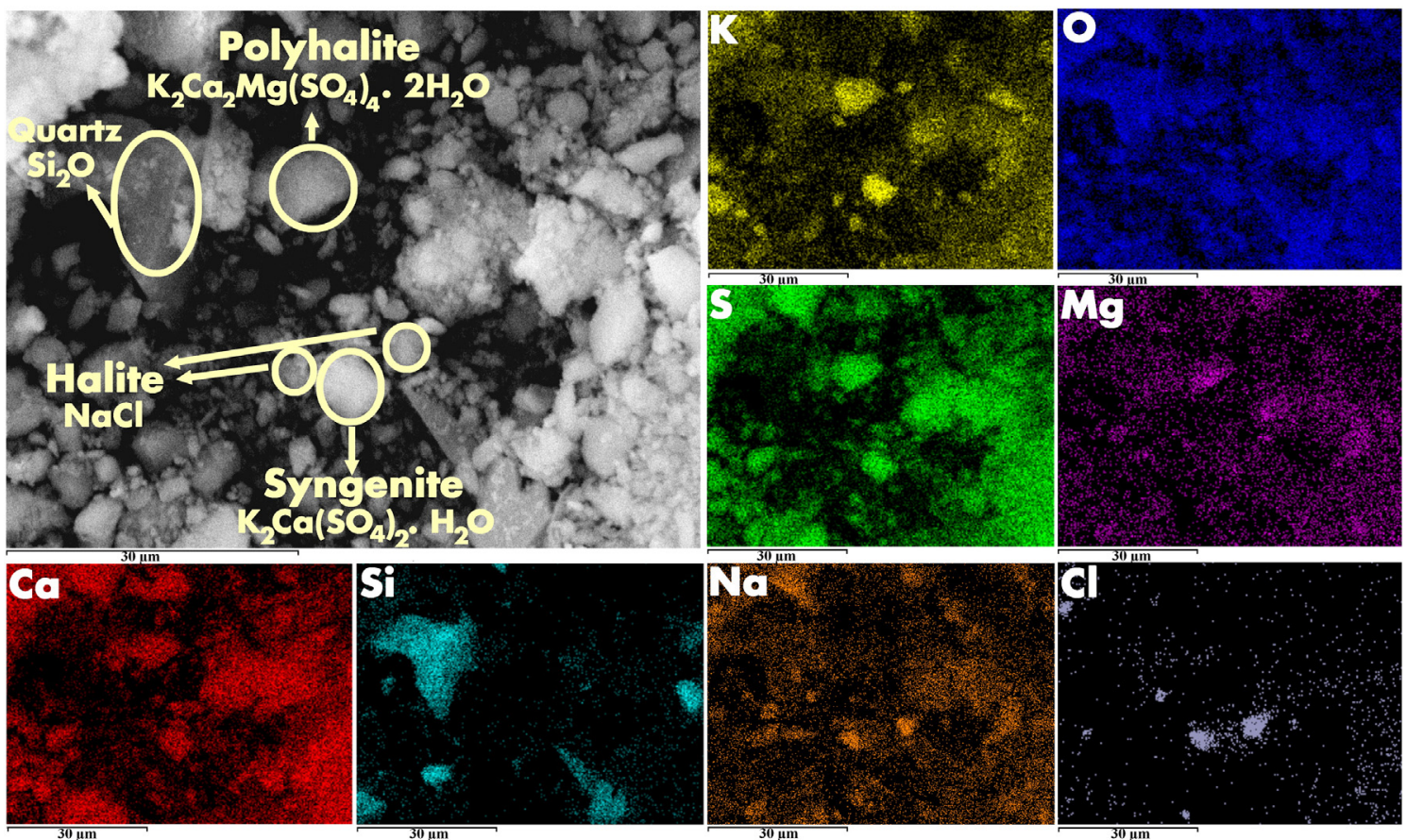

Fig. 4. SEM-EDS imaging showing the presence and distribution of halite, quartz, syngenite and polyhalite.

of high quantities of seagull drops were observed daily in the roof of the building. These drops are the responsible of the nitrate input in the building. Concretely, the ammonium is transformed into nitrates following a processes catalyzed by bacteria [20]. The non-transformed ammonium nitrate migrates downstream (to the walls of the inner rooms of the lighthouse) and it can react with the calcite based plaster, material also used in the Lighthouse construction. The acid ammonium ions react with the basic carbonate leading to the formation of niter $\left(\mathrm{KNO}_{3}\right)$ and nitratine $\left(\mathrm{NaNO}_{3}\right)[21]$.
The presence of the three $\mathrm{Na}^{+}, \mathrm{K}^{+}$and $\mathrm{NO}_{3}^{-}$ions seems to be related to the impact of marine aerosols that enters to the inner parts of the building through capillarity diffusion in the not well sealed walls of the lighthouse. The marine aerosol usually carries different inorganic compounds inside and/or dissolved ions like chlorides such as $\mathrm{NaCl}$, $\mathrm{KCl}, \mathrm{MgCl}_{2}, \mathrm{CaCl}_{2}$ [43]; nitrates such as $\mathrm{NaNO}_{3}$ [44], $\mathrm{Ca}\left(\mathrm{NO}_{3}\right)_{2}$ [45], $\mathrm{NH}_{4} \mathrm{NO}_{3}$ and $\mathrm{KNO}_{3}$ [46], $\mathrm{Mg}\left(\mathrm{NO}_{3}\right)_{2}$ [47]; sulfates such as $\mathrm{Na}_{2} \mathrm{SO}_{4}$ [48], $\mathrm{MgSO}_{4}$ [49], $\left(\mathrm{NH}_{4}\right)_{2} \mathrm{SO}_{4}$ [50] and even mixed-cation with $\mathrm{Na}, \mathrm{Mg}, \mathrm{K}$ and Ca sulfates [51].
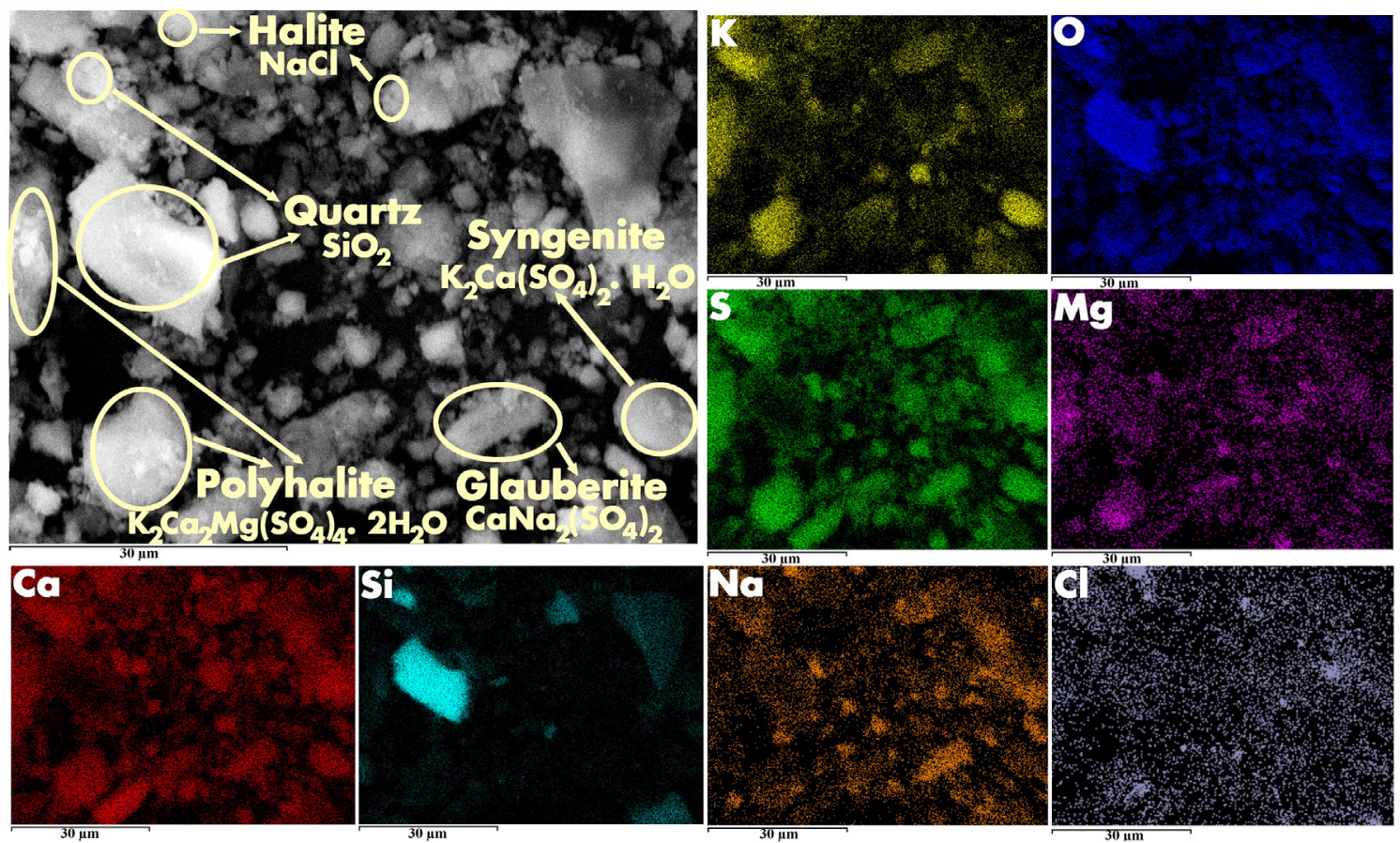

Fig. 5. SEM-EDS imaging showing the presence and distribution of halite, quartz, syngenite, polyhalite and glauberite. 

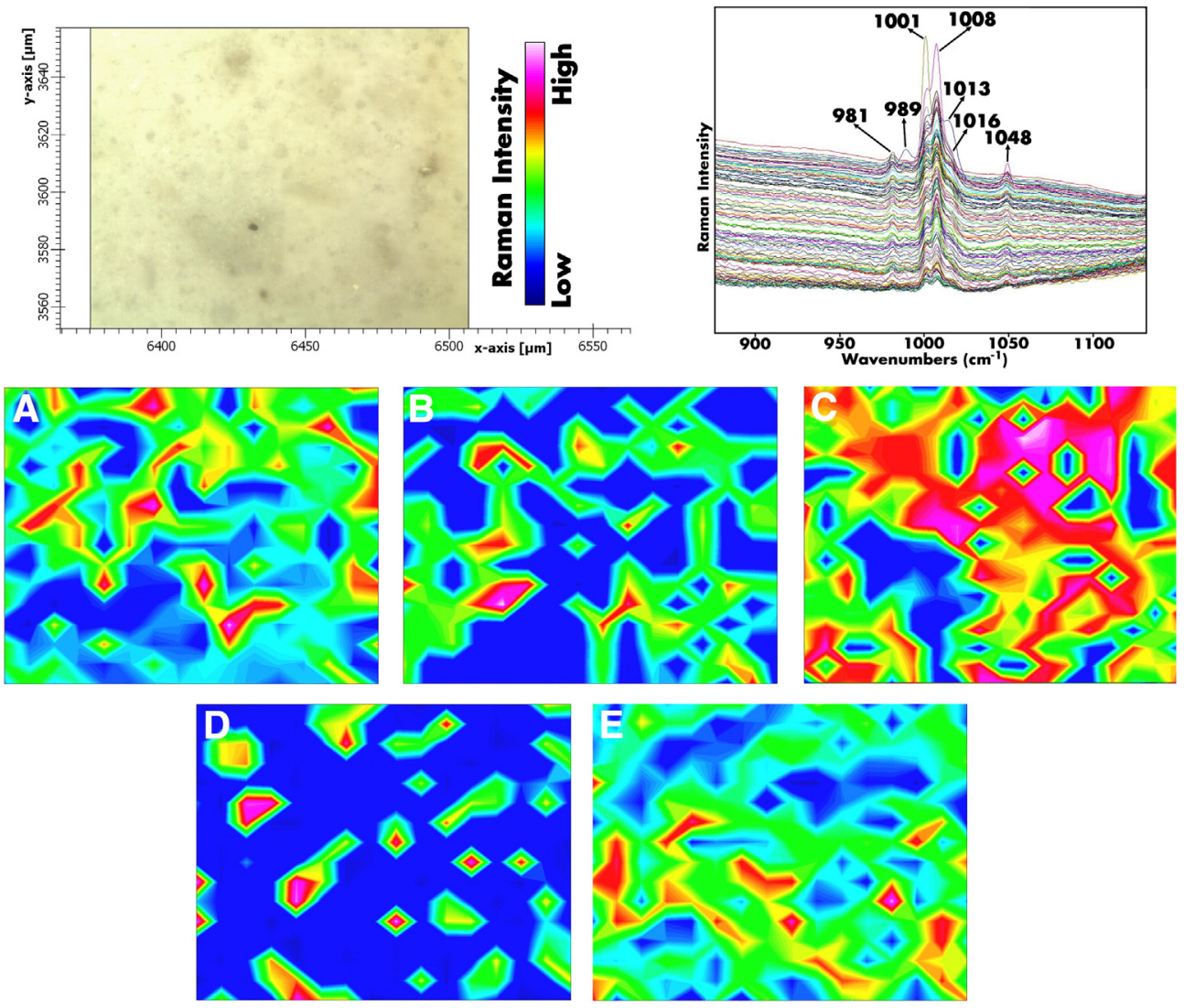

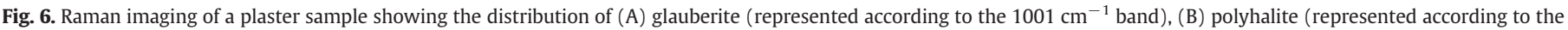

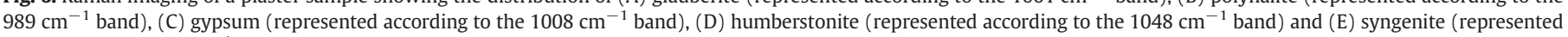
according to the $981 \mathrm{~cm}^{-1}$ band). The top left image shows the mapped area.

Moreover, as it has been described in the sampling section, plaster samples have been taken in a room where the average temperature depending on the season ranges between 27 and $35^{\circ} \mathrm{C}$. In this room all the machine system required for the proper functioning of the lighthouse is present. The complex systems of reactions that explain the decaying pathways occurring in the gypsum plaster of the inner areas of the Igueldo Lighthouse is summarized in Fig. 7 and are explained below.

The first decaying step starts with the partial dissolution of gypsum when the water from outside enter the inside walls reaching to the gypsum based plasters. Gypsum is not an insoluble compounds, having an intrinsic solubility due to the presence of the dissolved $\mathrm{CaSO}_{4}$ (dis) complex of the same stoichiometry than the solid phase. Then, this soluble complex $\left[\mathrm{CaSO}_{4}(\mathrm{dis})\right]$ dissociates in free calcium $\left(\mathrm{Ca}^{2+}\right)$ and sulfate $\left(\mathrm{SO}_{4}^{2-}\right)$ ions if the water content in the porous material is enough. When this water starts evaporating, the saturation condition of bassanite $\left(\mathrm{CaSO}_{4} \cdot \frac{1}{2} \mathrm{H}_{2} \mathrm{O}\right)$ is reached and this compound is precipitated. The whole set of interactions is summarized in Reaction 1:

$\mathrm{CaSO}_{4} \cdot 2 \mathrm{H}_{2} \mathrm{O}(\mathrm{s}) \leftrightarrows \mathrm{CaSO}_{4}(\mathrm{dis}) \leftrightarrows \mathrm{Ca}^{2+}+\mathrm{SO}_{4}^{2-}+\S \mathrm{H}_{2} \mathrm{O}(\mathrm{aq}) \leftrightarrows \mathrm{CaSO}_{4} \cdot \S \mathrm{H}_{2} \mathrm{O}(\mathrm{s})$

Table 2

Mineral phases identified in this work on/into the plaster matrix.

\begin{tabular}{|c|c|c|c|c|c|c|}
\hline Mineral phase & Chemical formula & Raman & XRD & ATR-FTIR & SEM-EDS & Raman imaging \\
\hline Gypsum & $\mathrm{CaSO}_{4} \cdot 2 \mathrm{H}_{2} \mathrm{O}$ & $\mathrm{X}$ & $\mathrm{X}$ & $\mathrm{X}$ & & $\mathrm{X}$ \\
\hline Bassanite & $\mathrm{CaSO}_{4} \cdot 1 / 2 \mathrm{H}_{2} \mathrm{O}$ & $\mathrm{X}$ & $\mathrm{X}$ & $\mathrm{X}$ & & $\mathrm{X}$ \\
\hline Anhydrite, types I,II, III & $\mathrm{CaSO}_{4}$ & $\mathrm{X}$ & & $\mathrm{X}$ & & \\
\hline Nitratine & $\mathrm{NaNO}_{3}$ & $\mathrm{X}$ & & & & \\
\hline Niter & $\mathrm{KNO}_{3}$ & $\mathrm{X}$ & & & & \\
\hline Thenardite & $\mathrm{Na}_{2} \mathrm{SO}_{4}$ & $\mathrm{X}$ & & & $\mathrm{X}$ & \\
\hline Mirabilite & $\mathrm{Na}_{2} \mathrm{SO}_{4} \cdot 10 \mathrm{H}_{2} \mathrm{O}$ & $\mathrm{X}$ & & & $\mathrm{X}$ & \\
\hline Mascagnite & $\left(\mathrm{NH}_{4}\right)_{2} \mathrm{SO}_{4}$ & $\mathrm{X}$ & & & & \\
\hline Starkeyite & $\mathrm{MgSO}_{4} \cdot 4 \mathrm{H}_{2} \mathrm{O}$ & $\mathrm{X}$ & & & & \\
\hline Hexahydrite & $\mathrm{MgSO}_{4} \cdot 6 \mathrm{H}_{2} \mathrm{O}$ & $\mathrm{X}$ & & & & \\
\hline Epsomite & $\mathrm{MgSO}_{4} \cdot 7 \mathrm{H}_{2} \mathrm{O}$ & $\mathrm{X}$ & & & & \\
\hline Halite & $\mathrm{NaCl}$ & & $\mathrm{X}$ & & $\mathrm{X}$ & \\
\hline Quartz & $\mathrm{SiO}_{2}$ & $\mathrm{X}$ & $\mathrm{X}$ & & $\mathrm{X}$ & \\
\hline Glauberite & $\mathrm{CaNa}_{2}\left(\mathrm{SO}_{4}\right)_{2}$ & $\mathrm{X}$ & $\mathrm{X}$ & $\mathrm{X}$ & $\mathrm{X}$ & $\mathrm{X}$ \\
\hline Polyhalite & $\mathrm{K}_{2} \mathrm{Ca}_{2} \mathrm{Mg}\left(\mathrm{SO}_{4}\right)_{4} \cdot 2 \mathrm{H}_{2} \mathrm{O}$ & $\mathrm{X}$ & $\mathrm{X}$ & $\mathrm{X}$ & $\mathrm{X}$ & $\mathrm{X}$ \\
\hline Syngenite & $\mathrm{K}_{2} \mathrm{Ca}\left(\mathrm{SO}_{4}\right) \cdot \mathrm{H}_{2} \mathrm{O}$ & $\mathrm{X}$ & $\mathrm{X}$ & $\mathrm{X}$ & $\mathrm{X}$ & $\mathrm{X}$ \\
\hline Humberstonite & $\mathrm{K}_{3} \mathrm{Na}_{7} \mathrm{Mg}_{2}\left(\mathrm{SO}_{4}\right)_{6}\left(\mathrm{NO}_{3}\right)_{2} \cdot 6 \mathrm{H}_{2} \mathrm{O}$ & $\mathrm{X}$ & $\mathrm{X}$ & $\mathrm{X}$ & & $\mathrm{X}$ \\
\hline Total identified & & 16 & 8 & 7 & 7 & 6 \\
\hline
\end{tabular}




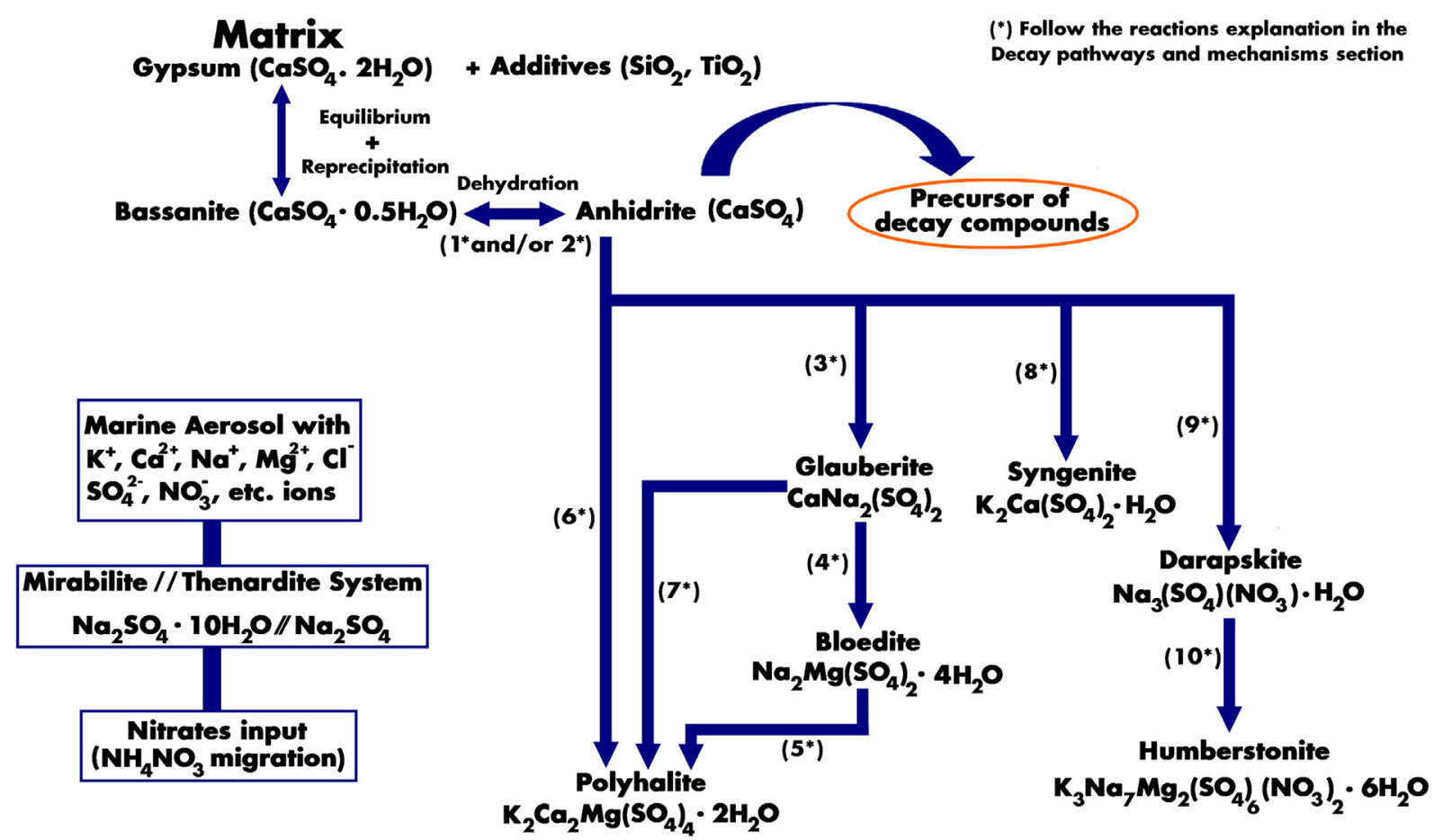

Fig. 7. Decay pathway reactions diagram, showing the reactions which lead to the formation of glauberite, bloedite, polyhalite, syngenite, darapskite and humberstonite.

When the temperature rises to the maximum (or simply with time), that water is completely evaporated and thus, anhydrite $\left(\mathrm{CaSO}_{4}\right)$ could be formed instead of bassanite, following Reaction 2:

$\mathrm{CaSO}_{4} \cdot 2 \mathrm{H}_{2} \mathrm{O}(\mathrm{s}) \leftrightarrows \mathrm{CaSO}_{4}(\mathrm{dis}) \leftrightarrows \mathrm{Ca}^{2+}+\mathrm{SO}_{4}^{2-} \leftrightarrows \mathrm{CaSO}_{4}(\mathrm{~s})$

As it was shown in a previous work, compounds such as thenardite $\left(\mathrm{Na}_{2} \mathrm{SO}_{4}\right)$ and mirabilite $\left(\mathrm{Na}_{2} \mathrm{SO}_{4} \cdot 10 \mathrm{H}_{2} \mathrm{O}\right)$ can be present in high quantities around this gypsum-based matrix if it suffers the impact of the marine aerosol [21]. Also the formation of other simple sulfates, like mascagnite $\left(\left(\mathrm{NH}_{4}\right)_{2} \mathrm{SO}_{4}\right)$, epsomite $\left(\mathrm{MgSO}_{4} \cdot 7 \mathrm{H}_{2} \mathrm{O}\right)$ and starkeyite $\left(\mathrm{MgSO}_{4} \cdot 4 \mathrm{H}_{2} \mathrm{O}\right)$, was explained [21]. However, in the present work we have identified a greater amount of mixed sulfates and their formation requires ascertaining the chemical reactions involved.

Some works in the literature mentioned that the precursor of many decay compounds, with large quantity of dissolved sulfates, is the anhydrite $\left(\mathrm{CaSO}_{4}\right)$ [52]. From anhydrite it is possible to find other compounds like glauberite $\left(\mathrm{CaNa}_{2}\left(\mathrm{SO}_{4}\right)_{2}\right)$ [53]. There are studies about the influence of saline environment in the formation of glauberite [54] or the possibility to obtain glauberite in a system with anhydrite, thenardite and water at $25{ }^{\circ} \mathrm{C}$ [55]. However, the formation of a solid phase directly from another solid phase is not always a thermodynamic favored process.

In our case, the three forms of solid calcium sulfate (gypsum, bassanite and anhydrite), when enter in contact with water, dissolve partially due to the presence of the soluble $\mathrm{CaSO}_{4}$ (dis) complex species, that dissociates to free calcium $\left(\mathrm{Ca}^{2+}\right)$ and sulfate $\left(\mathrm{SO}_{4}^{2-}\right)$ ions. If that water contains $\mathrm{Na}^{+}$from the marine aerosol, Reaction 3 is thermodynamically favored, leading to the formation of glauberite:

$\mathrm{Ca}^{2+}+2 \mathrm{SO}_{4}^{2-}+2 \mathrm{Na}^{+} \rightarrow \mathrm{CaNa}_{2}\left(\mathrm{SO}_{4}\right)_{2}(\mathrm{~s})$.

Glauberite has been proposed [56] as the precursor of the formation of other mixed sulfate compounds like polyhalite $\left(\mathrm{K}_{2} \mathrm{Ca}_{2} \mathrm{Mg}\left(\mathrm{SO}_{4}\right)_{4} \cdot 2 \mathrm{H}_{2} \mathrm{O}\right)$, that can also be formed through another intermediate compound such as bloedite $\left(\mathrm{Na}_{2} \mathrm{Mg}\left(\mathrm{SO}_{4}\right)_{2} \cdot 4 \mathrm{H}_{2} \mathrm{O}\right)$ (Reactions 4 and 5):

$\mathrm{CaNa}_{2}\left(\mathrm{SO}_{4}\right)_{2}(\mathrm{~s})+\mathrm{Mg}^{2+}+4 \mathrm{H}_{2} \mathrm{O} \rightarrow \mathrm{Na}_{2} \mathrm{Mg}\left(\mathrm{SO}_{4}\right)_{2} \cdot 4 \mathrm{H}_{2} \mathrm{O}(\mathrm{s})+\mathrm{Ca}^{2+}$

$\mathrm{Na}_{2} \mathrm{Mg}\left(\mathrm{SO}_{4}\right)_{2} \cdot 4 \mathrm{H}_{2} \mathrm{O}(\mathrm{s})+2 \mathrm{~K}^{+}+2 \mathrm{SO}_{4}^{2-} \rightarrow \mathrm{K}_{2} \mathrm{Ca}_{2} \mathrm{Mg}\left(\mathrm{SO}_{4}\right)_{4} \cdot 2 \mathrm{H}_{2} \mathrm{O}(\mathrm{s})$ $+2 \mathrm{H}_{2} \mathrm{O}$.

In this point, it is necessary to highlight that in the measurements performed in the gypsum plaster, it was not possible to find bloedite, but its presence should not be discarded. However, Reactions 4 and 5 starts from a solid phase, ending in another solid phase, a process that could not be completed due to passivation side-reactions. To overcome this problem, there are authors that suggest the direct formation of polyhalite from anhydrite impacted by a constant source of $\mathrm{K}^{+}$and $\mathrm{Mg}^{2+}$ coming from marine aerosol, in form of $\mathrm{MgSO}_{4}$ and $\mathrm{K}_{2} \mathrm{SO}_{4}$, under less than $30^{\circ} \mathrm{C}$ temperature conditions [57] (Reaction 6):

$2 \mathrm{CaSO}_{4}+2 \mathrm{~K}^{+}+\mathrm{Mg}^{2+}+2 \mathrm{SO}_{4}^{2-}+2 \mathrm{H}_{2} \mathrm{O} \rightarrow \mathrm{K}_{2} \mathrm{Ca}_{2} \mathrm{Mg}\left(\mathrm{SO}_{4}\right)_{4} \cdot 2 \mathrm{H}_{2} \mathrm{O}(\mathrm{s})$.

Apart from this, there is another work that mentions the possibility to obtain polyhalite from glauberite [58] but the reaction starts from two solid phases (Reaction 7):

$$
\begin{aligned}
& \mathrm{CaNa}_{2}\left(\mathrm{SO}_{4}\right)_{2}(\mathrm{~s})+2 \mathrm{~K}^{+}+\mathrm{CaMg}\left(\mathrm{SO}_{4}\right)_{2}(\mathrm{~s})+2 \mathrm{H}_{2} \mathrm{O} \rightarrow \mathrm{K}_{2} \mathrm{Ca}_{2} \mathrm{Mg}\left(\mathrm{SO}_{4}\right)_{4} \cdot 2 \mathrm{H}_{2} \mathrm{O}(\mathrm{s}) \\
& \quad+2 \mathrm{Na}^{+} .
\end{aligned}
$$

However, polyhalite can be formed from the dissolved calcium $\left(\mathrm{Ca}^{2+}\right)$ and sulfate $\left(\mathrm{SO}_{4}^{2-}\right)$ ions (dissociated from the soluble $\mathrm{CaSO}_{4}(\mathrm{dis})$ complex) that enter in contact with dissolved $\mathrm{K}^{+}$and $\mathrm{Mg}^{2+}$ from the marine aerosol, following a similar reaction like 6 . Even the formation of bloedite can be explained by the interaction (direct reaction) of $\mathrm{SO}_{4}^{2-}$ with $\mathrm{Na}^{+}$(from $\mathrm{NaCl}$ ) and $\mathrm{Mg}^{2+}$ (from $\mathrm{MgCl}_{2}$ or $\mathrm{MgSO}_{4}$ or both) also from the marine aerosol.

The formation of syngenite $\left(\mathrm{K}_{2} \mathrm{Ca}\left(\mathrm{SO}_{4}\right)_{2} \cdot \mathrm{H}_{2} \mathrm{O}\right)$ can be explained by the interaction of $\mathrm{K}^{+}$from the marine aerosol with the dissolved 
Considering that sulfate ions are consumed when the new sulfate phases are formed, an additional situation in which the concentration of sulfate ions is not so high was necessary to be taken into account. The competition among phases can be seen in Fig. $8 \mathrm{C}$ when the relative magnesium $\left(\mathrm{Mg}^{2+}\right.$ input can come from marine aerosol) concentration increases. When the concentration of $\mathrm{Mg}^{2+}$ reaches to a certain level, the presence of mirabilite starts decreasing while epsomite $\left(\mathrm{MgSO}_{4} \cdot 7 \mathrm{H}_{2} \mathrm{O}\right)$ is formed, being syngenite nearly constant.

When we considered the same situation (lower concentrations of sulfate ions), but at lower concentrations of $\mathrm{Ca}^{2+}$, a similar tendency was observed, but in this case epsomite together with gypsum are formed (see Fig. 8D). In our previous analysis performed on the plaster from the Igueldo lighthouse [21], the simultaneous presence of epsomite and gypsum was always detected in the Raman spectra. This thermodynamic simulation means that it is possible to observe the formation of epsomite in the gypsum plaster of Igueldo Lighthouse at relative high concentrations of $\mathrm{Mg}^{2+}$ and lower concentrations of dissolved $\mathrm{SO}_{4}^{2-}$ in the plaster. In this way, the magnesium coming from marine aerosol in form of sulfates or chlorides seems to have also an important role in the chemical decaying of the system.

Finally for the formation of the most complex mixed compound identified in this work, humberstonite $\left(\mathrm{K}_{3} \mathrm{Na}_{7} \mathrm{Mg}_{2}\left(\mathrm{SO}_{4}\right)_{6}\left(\mathrm{NO}_{3}\right)_{2} \cdot 6 \mathrm{H}_{2} \mathrm{O}\right)$, it seems to require firstly the formation of darapskite $\left(\mathrm{Na}_{3}\left(\mathrm{SO}_{4}\right)\left(\mathrm{NO}_{3}\right)\right.$. $\mathrm{H}_{2} \mathrm{O}$ ) [52,62], by the input of dissolved $\mathrm{Na}^{+}$coming from marine aerosol and the input of nitrates from other sources, (seagull dropping and/or marine aerosol), as suggested elsewhere [20] on the dissolved $\mathrm{CaSO}_{4}(\mathrm{dis})$ complex species (Reaction 9):

$\mathrm{CaSO}_{4}($ dis $)+3 \mathrm{Na}^{+}+\mathrm{NO}_{3}^{-}+\mathrm{H}_{2} \mathrm{O} \rightarrow \mathrm{Na}_{3}\left(\mathrm{SO}_{4}\right)\left(\mathrm{NO}_{3}\right) \cdot \mathrm{H}_{2} \mathrm{O}(\mathrm{s})+\mathrm{Ca}^{2+}$

After the formation of darapskite, this compound can be transformed, by the input of dissolved $\mathrm{K}^{+}$and $\mathrm{Mg}^{2+}$ from the marine environment, to humberstonite following Reaction 10:

$2 \mathrm{Na}_{3}\left(\mathrm{SO}_{4}\right)\left(\mathrm{NO}_{3}\right) \cdot \mathrm{H}_{2} \mathrm{O}+2 \mathrm{Mg}^{2+}+3 \mathrm{~K}^{+}+\mathrm{Na}^{+}+4 \mathrm{SO}_{4}^{2-}$

$+5 \mathrm{H}_{2} \mathrm{O} \rightarrow \mathrm{K}_{3} \mathrm{Na}_{7} \mathrm{Mg}_{2}\left(\mathrm{SO}_{4}\right)_{6}\left(\mathrm{NO}_{3}\right)_{2} \cdot 6 \mathrm{H}_{2} \mathrm{O}$

Other authors suggest the formation of humberstonite by repeated natural leaching of nitrates over sulfate bearing materials [42,52,63], as well as the consequence of the reaction between dissolved sulfates coming from the plaster and sodium nitrate coming from the marine aerosol [9].

\section{Conclusions}

The principal source of deterioration affecting gypsum-based plasters of the interior areas of Igueldo Lighthouse is the marine aerosol (and rain charged with seawaters) which enters to the inner parts of the walls trough cracks and pores from the outside walls of the building. The reaction of the different ions of the marine aerosol with the dissolved calcium and sulfate ions present in the matrix leads to the formation of a wide variety of compounds, most of them well crystallized as revealed the XRD analyses.

The analytical methodology, combining XRD, SEM-EDS, ATR-FTIR and micro Raman spectroscopy (point-by-point and imaging), was required to identify the presence of the whole set of compounds summarized in Table 2. The combined use of Raman and XRD measurements identified most of the new complex compounds. Chloride salts were also identified by using XRD and SEM-EDX measurements on the samples from gypsum plasters, suggesting that the input of sodium and magnesium, also present in the new crystals, can come from the chlorides transported by the marine aerosol (e.g. $\mathrm{NaCl}, \mathrm{MgCl}_{2}, \mathrm{KCl}$ ) [8].

Regarding the new salts crystallized in the plaster, it has been possible to assign the main Raman bands of the double sulfate-nitrate salt humberstonite $\left(\mathrm{K}_{3} \mathrm{Na}_{7} \mathrm{Mg}_{2}\left(\mathrm{SO}_{4}\right)_{6}\left(\mathrm{NO}_{3}\right)_{2} \cdot 6 \mathrm{H}_{2} \mathrm{O}\right)$. X-ray diffraction (XRD) and attenuated total reflectance infrared (ATR-FTIR) analyses confirmed the presence of humberstonite. Apart from this salt, glauberite $\left(\mathrm{CaNa}_{2}\left(\mathrm{SO}_{4}\right)_{2}\right)$, syngenite $\left(\mathrm{K}_{2} \mathrm{Ca}\left(\mathrm{SO}_{4}\right)_{2} \cdot \mathrm{H}_{2} \mathrm{O}\right)$ and polyhalite $\left(\mathrm{K}_{2} \mathrm{Ca}_{2} \mathrm{Mg}\left(\mathrm{SO}_{4}\right)_{4} \cdot 2 \mathrm{H}_{2} \mathrm{O}\right)$ were also identified by means of Raman spectroscopy. The presence of these salts was corroborated by means of XRD and ATR-FTIR. For instance, the efficiency of Raman scattering arises from the big intensity of the symmetric stretching mode of well defined molecular ions such as $\mathrm{NO}_{3}^{-}, \mathrm{CO}_{3}^{2-}, \mathrm{SO}_{4}^{2-}$, etc., whatever the orientation of the analyzed crystal. Efflorescence salts usually form well defined crystals with anisotropic shape and thus bending mode intensity occurring in the $300-700 \mathrm{~cm}^{-1}$ range is very dependent of the analyzed spot. Furthermore bending modes have $\mathrm{E}$ or $\mathrm{F}$ character that implies many modes at very close wavenumbers. This implies overlapping of $\mathrm{NO}_{3}^{-}$and $\mathrm{SO}_{4}^{2-}$ bending modes and their identification/use requires chemometric techniques. For all these reason the symmetric stretching bands are the most useful for phase identification if the instrument resolution is sufficient to separate the different peaks. The vibrational infrared spectra counterpart arises from the asymmetric stretching modes with generally F character, i.e. three bands. Thus the overlapping is important and phase identification is difficult.

Therefore, the combined use in these X-ray based and vibrational spectroscopic techniques was proven to be an adequate analytical methodology to avoid inaccurate assignments that can be done only using only one spectroscopic technique. Moreover, the use of the images from SEM-EDS and Raman allowed us to confirm the complex distribution of the new salts in the whole matrix.

Considering all the new mineral phases identified, a complete decaying pathway diagram, containing several reactions, was proposed. In this diagram, gypsum, bassanite and anhydrite are the precursors of the new crystalline phases, through its partial dissolution as the $\mathrm{CaSO}_{4}$ (dis) complex species. The different calcium sulfates, in continuous contact with the marine environment and other surrounding sources of chemicals, like $\mathrm{NH}_{4} \mathrm{NO}_{3}$, experiment different reactions giving rise to new sulfates and double sulfate/nitrate salts. These compounds are primarily sub- and/or crypto-efflorescences which during time will affect the integrity and durability of the material (in this case gypsum) as well as the aesthetic appearance of the interior facades. In some areas of the rooms, the tiles covering some walls were being detached due to the formation of these new salts in the gypsum plaster placed under the tiles, which weaken its role as a joint mortar.

This more in-depth work on gypsum based materials, complements the previous works $[20,21]$ developed on other kind of building materials (carbonate and sandstone based materials) also from inside of the Igueldo Lighthouse (San Sebastian, Basque Country, north of Spain) where different kind of pathologies can be explained by the chemical reactivity between original materials and ions transported by the marine aerosol, with the contribution in this particular case of seagull dropping, as an extra source of ammonium and nitrate.

\section{Acknowledgments}

This work has been developed under the project DISILICA-1930 (ref. BIA2014-59124) funded by the Spanish Ministry of Economy and Competitiveness (MINECO) and the Regional Development Fund (FEDER). H. Morillas is grateful to the University of the Basque Country (UPV/ EHU) and mainly to the action UFI 11-26 Global Change and Heritage, who funded his pre-doctoral contract. The stage of $\mathrm{H}$. Morillas in Paris was supported by the Unesco Chair of Cultural Landscape and Heritage (UPV/EHU). Technical support provided by the Raman-LASPEA laboratory and the general X-ray service: Unit of Rocks and Minerals, from the Advanced Research Facilities-SGIker (UPV/EHU, MICINN, GV/EJ, ERDF and ESF) is also gratefully acknowledged.

\section{References}

[1] N. Prieto-Taboada, O. Gomez-Laserna, I. Martinez-Arkarazo, M.A. Olazabal, J.M. Madariaga, Anal. Chem. 86 (2014) 10131-10137.

[2] A.N. Christensen, M. Olesen, Y. Cerenius, T.R. Jensen, Chem. Mater. 20 (2008) 2124-2132. 
[3] P.W. Mirwald, J. Chem. Phys. 128 (2008) 074502/1-074502/7.

[4] P. Comodi, A. Kurnosov, S. Nazzareni, L. Dubrovinsky, Phys. Chem. Miner. 39 (2012) 65-71.

[5] M. Prisciandaro, A. Lancia, D. Musmarra, Ind. Eng. Chem. Res. 40 (2001) 2335-2339.

[6] M. Prisciandaro, A. Lancia, D. Musmarra, Ind. Eng. Chem. Res. 42 (2003) 6647-6652

[7] T.H. Chong, R. Sheikholeslami, Chem. Eng. Sci. 56 (2001) 5391-5400.

[8] S.B. Ahmed, M.M. Tlili, M. Amami, M.B. Amor, Ind. Eng. Chem. Res. 53 (2014) 9554-9560.

[9] A.U. Lewandowska, L.M. Falkowska, Oceanologia 55 (2013) 279-298.

[10] L. Miñambres, E. Méndez, M.N. Sánchez, F. Castaño, F.J. Basterretxea, Atmos. Chem. Phys. 14 (2014) 11409-11425.

[11] J. Tursîc, B. Podkrajŝek, I. Grgić, P. Ctyroky, A. Berner, U. Dusek, R. Hitzenberger, Chemosphere 63 (2006) 1193-1202.

[12] T.L. Guasco, L.A. Cuadra-Rodriguez, B.E. Pedler, A.P. Ault, D.B. Collins, D. Zhao, M.J. Kim, M.J. Ruppel, S.C. Wilson, R.S. Pomeroy, V.H. Grassian, F. Azam, T.H. Bertram, K.A. Prather, Environ. Sci. Technol. 48 (2014) 1324-1333.

[13] L. Xia, Y. Gao, Mar. Chem. 119 (2010) 77-90.

[14] M. Viana, J. Pey, X. Querol, A. Alastuey, F. de Leeuw, A. Lükewille, Sci. Total Environ. 472 (2014) 825-833.

[15] S.C. Pryor, R.J. Barthelmie, J.T. Schoof, F.S. Binkowski, L. Delle Monache, R. Stull, Sci. Total Environ. 391 (2008) 132-142.

[16] D. Freyer, W. Voigt, Geochim. Cosmochim. Acta 68 (2004) 307-318.

[17] F. Zezza, F. Macri, Sci. Total Environ. 167 (1995) 123-143.

[18] A.E. Charola, J. Pühringer, M. Steiger, Environ. Geol. 52 (2007) 339-352.

[19] I. Martinez-Arkarazo, M. Angulo, L. Bartolome, N. Etxebarria, M.A. Olazabal, J.M. Madariaga, Anal. Chim. Acta 584 (2007) 350-359.

[20] H. Morillas, M. Maguregui, O. Gómez-Laserna, J. Trebolazabala, J.M. Madariaga, J. Raman, Spectroscopy 43 (2012) 1630-1636.

[21] H. Morillas, M. Maguregui, O. Gómez-Laserna, J. Trebolazabala, J.M. Madariaga, J. Raman, Spectroscopy 44 (2013) 1700-1710.

[22] N. Prieto-Taboada, I. Ibarrondo, O. Gomez-Laserna, I. Martinez-Arkarazo, M.A. Olazabal, J.M. Madariaga, J. Hazard. Mater. 248-249 (2013) 451-460.

[23] N. Prieto-Taboada, M. Maguregui, I. Martinez-Arkarazo, M.A. Olazabal, G. Arana, J.M. Madariaga, Anal. Bioanal. Chem. 399 (2011) 2949-2959.

[24] L. Bityukova, Water Air Soil Pollut. 172 (2006) 239-271.

[25] R.C. Clark, R.R. Hark, N. Salvadó, S. Butí, T.J. Pradell, J. Raman Spectrosc. 41 (2010) 1418-1424.

[26] T. Aguayo, E. Clavijo, F. Eisner, C. Ossa-Izquierdo, M.M. Campos-Vallette, J. Raman Spectrosc. 42 (2011) 2143-2148.

[27] M. Maguregui, U. Knuutinen, I. Martinez-Arkarazo, A. Giakoumaki, K. Castro, J.M. Madariaga, J. Raman Spectrosc. 43 (2012) 1747-1753.

[28] A. Hamilton, R.I. Menzies, J. Raman Spectrosc. 41 (2010) 1014-1020.

[29] H. Morillas, M. Maguregui, J. Trebolazabala, J.M. Madariaga, Spectrochim. Acta A 136 (2015) 1195-1203.

[30] V. Matovic, S. Eric, D. Sreckovic-Batocanin, P. Colomban, A. Kremenovic, Environ. Earth Sci. 72 (2014) 1939-1951.

[31] V.P. Jentzsch, V. Ciobotâ, B. Kampe, P. Rösch, J. Popp, J. Raman Spectrosc. 43 (2012) 514-519.

[32] L.C. Prinsloo, J. Raman Spectrosc. 38 (2007) 496-503.

[33] P.F. Weck, E. Kim, C.F. Jové-Colón, D.C. Sassani, Chem. Phys. Lett. 594 (2014) 1-5.

[34] G. Zhou, K. Tazaki, Atmos. Environ. 30 (1996) 3301-3308.
[35] R.T. Downs, Program and abstracts of the 19th general meeting of the international mineralogical association in Kobe, Japan, O03-13, , 2006 (http://rruff.info/index.php).

[36] K. Castro, M. Perez, M.D. Rodriguez-Laso, J.M. Madariaga, Anal. Chem. 75 (2003) 214A-221A.

[37] M. Maguregui, N. Prieto-Taboada, J. Trebolazabala, N. Goienaga, N. Arrieta, J. Aramendia, L. Gomez-Nubla, A. Sarmiento, M. Olivares, J.A. Carrero, I. Martinez-Arkarazo, K. Castro, G. Arana, M.A. Olazabal, L.A. Fernandez, J.M. Madariaga, CHEMCH 1st International Congress Chemistry for Cultural Heritage, Ravenna, 2010

[38] I. Puigdomenech, A. Zagorodni, M. Wang, M. Muhammed, Program Medusa MEDUSA (Make Equilibrium Diagrams Using Sophisticated Algorithms), The Royal Institute of Technology, Inorganic and Materials Chemistry, Stockholm, 2009. (https://www.kth.se/en/che/medusa [last accessed, April 2015]).

[39] http://wwcvw.iupac.org/index.php?id=410 [last accessed, April 2015].

[40] http://www.lwr.kth.se/English/OurSoftware/vminteq/ (last accessed, April 2015).

[41] B. Minčeva-Šukarova, A. İssi, A. Raškovska, O. Grupče, V. Tanevska, M. Yaygingöl, A. Kara, P. Colomban, J. Raman Spectrosc. 43 (2012) 792-798.

[42] M.E. Mrose, J.J. Fahey, G.E. Eriksen, Am. Mineral. 55 (1970) 1518-1533.

[43] J.H. Park, A.V. Ivanov, M.J. Molina, J. Phys. Chem. A 112 (2008) 6968-6977.

[44] A. Laskin, M.J. Iedema, J.P. Cowin, Environ. Sci. Technol. 36 (2002) 4948-4955.

[45] S.M. Griffith, X.H.H. Huang, P.K.K. Louie, J.Z. Yu, Atmos. Environ. (2015)http://dx.doi. org/10.1016/j.atmosenv.2015.02.009 (Available online at:).

[46] L. Bencs, K. Ravindra, J. de Hoog, E.O. Rasoazanany, F. Deutsch, N. Bleux, P. Berghmans, E. Roekens, A. Krata, R. Van Grieken, J. Environ. Monit. 10 (2008) $1148-1157$

[47] E. Woods, K.D. Heylman, A.K. Gibson, A.P. Ashwell, S.R. Rossi, J. Phys. Chem. A 117 (2013) 4214-4222.

[48] I.N. Tang, A.C. Tridico, K.H. Fung, J. Geophys. Res.-Atmos. 102 (D19) (1997) 23269-23275.

[49] E. Woods, D. Chung, H.M. Lanney, B.A. Ashwell, J. Phys. Chem. A 114 (2010) 2837-2844.

[50] J. Nicolás, M. Chiari, J. Crespo, N. Galindo, F. Lucarelli, S. Nava, E. Yubero, Tellus 63B (2011) 96-106.

[51] M. Pòsfai, J.R. Anderson, P.R. Buseck, H. Sievering, J. Geophys. Res.-Atmos. 100 (D11) (1995) 23063-23074.

[52] J.J. Pueyo, G. Chong, M. Vega, Rev. Geol. Chile 25 (1998) 03-15.

[53] P.V. Jentzsch, R.M. Bolanz, V. Ciobotâ, B. Kampe, P. Rösch, J. Majzlan, J. Popp, Vib. Spectrosc. 61 (2012) 206-213.

[54] A. Chabas, R.A. Lefèvre, Atmos. Environ. 34 (1999) 225-238.

[55] D. Popovic, G. Stupar, J. Miladinovic, M. Todorovic, M. Zrilic, Russ. J. Phys. Chem. A 85 (2011) 2349-2353.

[56] S. Collao, E. Arce, A. Andia, Bol. Soc. Chil. Quim. 47 (2002) 181-190.

[57] T.M. Peryt, C. Pierre, S.P. Gryniv, Sedimentology 45 (1998) 565-578.

[58] C.E. Harvie, J.H. Weare, L.A. Hardie, H.P. Eugster, Science 208 (1980) 498-500.

[59] J.T. Kloprogge, R.D. Schuiling, Z. Ding, L. Hickey, D. Wharton, R.L. Frost, Vib. Spectrosc. 28 (2002) 209-221.

[60] J.T. Kloprogge, Z. Ding, W.N. Martens, R.D. Schuiling, L.V. Duong, R.L. Frost, Thermochim. Acta 417 (2004) 143-155.

[61] J. Dankiewicz, K. Wieczorek-Ciurowa, J. Therm. Anal. 13 (1978) 543-552.

[62] P.C. Burns, F.C. Hawthorne, Can. Mineral. 32 (1994) 381-385.

[63] G.E. Ericksen, J.W. Hosterman, P.St. Amand, Chem. Geol. 67 (1988) 85-102. 